\title{
BEZPIECZEŃSTWO OBROTU PRAWNO- -FINANSOWEGO. OBOWIAZZKI NOTARIUSZA W ŚWIETLE USTAWY O PRZECIWDZIAŁANIU PRANIU PIENIĘDZY ORAZ FINANSOWANIU TERRORYZMU
}

\section{Wprowadzenie}

Bezpieczeństwo obrotu prawnego oraz finansowego stanowi wartość, której zapewnienie oraz ochrona jest celem rozwiązań przewidzianych w systemie prawa. Są one zawarte zarówno w prawie ustrojowym jak i poszczególnych dziedzinach prawa, tak materialnego jak i procesowego, prywatnego jak i publicznego. Analizowane w artykule zagadnienie dotyczy jednego z aspektów tej problematyki, mianowicie roli notariusza w zwalczaniu przestępczości związanej z praniem brudnych pieniędzy oraz finansowaniem terroryzmu. Gwarancjami dla zapewnienia bezpieczeństwa obrotu prawnego jest przyjęty w systemie prawa model notariatu, w tym szczegółowe rozwiązania dotyczące statusu notariusza jako funkcjonariusza publicznego, wymogi co do wykształcenia oraz cech osobistych notariusza. Istotne są także przepisy prawa cywilnego materialnego, przewidujące wymóg dokonania pewnych czynności prawnych w formie aktu notarialnego, zweryfikowanych w ramach tzw. notarialnej jurysdykcji prewencyjnej oraz przepisy prawa procesowego, głównie w zakresie mocy dowodowej aktów notarialnych. Katalog „tradycyjnie”

\footnotetext{
* Dr Justyna Holocher - Katedra Polityki Publicznej, Instytut Politologii, Uniwersytet Pedagogiczny im. Komisji Edukacji Narodowej w Krakowie.
} 
nakładanych na notariuszy obowiązków uzupełniony został obowiązkami wynikającymi z ustawy o przeciwdziałaniu praniu pieniędzy oraz finansowaniu terroryzmu, których celem jest ochrona obrotu finansowego ${ }^{1}$. Ocena tej regulacji dokonana zostanie z perspektywy założeń przyjętych w systemie prawnym jak również z perspektywy faktycznych możliwości ich realizacji.

\section{Notariusz jako funkcjonariusz publiczny i podmiot obowiązany}

\subsection{Polski model notariatu. Status i obowiązki notariusza}

Notariusz w zakresie przyznanych ustawowo uprawnień działa jako osoba zaufania publicznego, korzystająca z ochrony przysługującej funkcjonariuszom publicznym. Jego status w systemie prawnym, w tym jego obowiązki oraz podstawy i zakres odpowiedzialności określa Prawo o notariacie ${ }^{2}$. Powierzone obowiązki notariusz wykonywać ma zgodnie z prawem i sumieniem, dochować tajemnicy zawodowej, w postępowaniu swym kierować się zasadami godności, honoru i uczciwości, zachowując wysoki stopień staranności ${ }^{3}$. Notariusz jest obowiązany czuwać nad należytym zabezpieczeniem praw i słusznych interesów stron oraz innych osób, dla których czynność ta może powodować skutki prawne. Ma być także lojalny wobec Państwa ${ }^{4}$. Notariusz sporządzający akt nie jest osobą wyłącznie „odbierającą” czy „poświadczającą” oświadczenia stron, a osobą kontrolującą

$1 \quad$ W dniu 25.6.2009 r. została uchwalona ustawa o zmianie ustawy o przeciwdziałaniu wprowadzaniu do obrotu finansowego wartości majątkowych pochodzących z nielegalnych lub nieujawnionych źródeł oraz o przeciwdziałaniu finansowaniu terroryzmu oraz o zmianie niektórych innych ustaw, która otrzymała brzmienie: ustawa o przeciwdziałaniu praniu pieniędzy oraz finansowaniu terroryzmu (weszła w życie 22.10.2009 r.). Służy ona wdrażaniu dyrektywy 2005/60/ WE Parlamentu Europejskiego i Rady UE z 26.10.2005 r. w sprawie przeciwdziałania korzystaniu z systemu finansowego w celu prania pieniędzy oraz finansowania terroryzmu; zob. także http:// www.msz.gov.pl/pl/polityka_zagraniczna/polityka_bezpieczenstwa/zwalczanie_terroryzmu_miedzynarodowego/zagrozenie_terrorystyczne_w_polsce_i_regionie/walka_z_finansowaniem_terroryzmu/walka_z_finansowaniem_terroryzmu?printMode=true (dostęp 7.7.2015 r.); http://www. mf.gov.pl/ministerstwo-finansow/dzialalnosc/giif/system, (dostęp 7.7.2015 r.); http://www.mf.gov. pl/ministerstwo-finansow/dzialalnosc/giif/raportowanie-transakcji, (dostęp 7.7.2015 r.), http:// www.bip.kprm.gov.pl/download.php?s=75\&id=12690 (dostęp 7.7.2015 r.).

${ }^{2}$ Art. 1 §1 Prawa o notariacie (t.j.: Dz.U. z 2008 r. Nr 189, poz. 1158 ze zm. Szczegółowy katalog czynności notarialnych przewiduje art. 79. Pośrednio obowiązki notariusza określają również przepisy prawa materialnego, które są podstawą podejmowanych przez notariusza czynności, a po części także przepisy proceduralne w szczególności w zakresie mocy dowodowej dokumentów; zob. wyrok SN z 12.6.2002 r., sygn. akt III CKN 694/00, „Biuletyn Sądu Najwyższego” 2003, nr 1, s. 10.

$3 \quad$ Art. 15 ustawy z 14.21991 r. Prawo o notariacie.

$4 \quad$ Do zasad tych odwołuje się również Kodeks Etyki Zawodowej Notariusza, Uchwała Nr 19 (ze zm.) Krajowej Rady Notarialnej z 12.12.1997 r., Preambuła, §11, §15. 
zarówno legalność dokonanej przez strony czynności prawnej, jak i jej celowość 5 . Zakres przewidzianych uprawnień i fakt, że działa zarówno w interesie prywatnym i jak i publicznym dowodzi, że jest on gwarantem bezpieczeństwa obrotu prawnego. Realizacja interesu prywatnego polega na kształtowaniu majątkowych i niemajątkowych interesów podmiotów prawnych w sytuacji gdy chcą lub są zobligowani do nadania czynności prawnej formy aktu notarialnego. $Z$ kolei realizacja interesu publicznego sprowadza się do obowiązku zapewnienia bezpieczeństwa obrotu prawnego, a więc stworzenia gwarancji legalności i przejrzystości dokonywanych czynności z perspektywy potencjalnych i rzeczywistych uczestników obrotu prawnego. Wiąże się to z budowaniem zaufania co do zgodności z prawem oraz poprawności funkcjonujących w sferze prawnej dokumentów, potwierdzających prawa i obowiązki osób fizycznych i prawnych ${ }^{6}$. Wykonywanie tych czynności obwarowane jest odpowiedzialnością cywilną, dyscyplinarną oraz karną?.

Podsumowując, powiedzieć należy, że notariusz jest wyspecjalizowanym podmiotem zapewniającym bezpieczeństwo, pewność i przewidywalność obrotu prawnego ${ }^{8}$. Czynności notarialne bowiem, jeżeli są zgodne z prawem, zyskują

$5 \quad$ R. Trzaskowski, Nieważność czynności prawnej dokonanej w formie aktu notarialnego [w:] E. Holewińska- Łapińska, Prawo w działaniu. Sprawy cywilne, Warszawa, 2012, s. 7; A. Oleszko, Obrót cywilnoprawny w praktyce notarialnej i wieczystoksięgowej, Kraków 2003, s. 31, zob. E. Gniewek, O uniwersalnej zasadzie przestrzegania prawa przez notariusza [w:] II Kongres Notariuszy Rzeczypospolitej Polskiej, red. R. Sztyk, Poznań-Kluczbork 1999, s. 45-46; R. Pastuszko, Obowiq̨zek wyjaśniajaco-doradczy notariusza a wystuchanie stron czynności prawnej [w:] III Kongres Notariuszy Rzeczypospolitej Polskiej. Referaty i opracowania, red. R. Sztyk, Warszawa-Kluczbork 2006, s. 269; J. Budzianowska, Odmowa dokonania czynności notarialnej, „Nowy Przegląd Notarialny” 2000, nr 1, s. 47-48, 55.

$6 \quad$ Art. 2 § 2 Prawa o notariacie; E. Drozd, Odpowiedzialność notariusza w wypadku nieważnej (bezskutecznej) czynności prawnej [w:] III Kongres Notariuszy Rzeczypospolitej Polskiej. Referaty i opracowania, red. R. Sztyk, Warszawa-Kluczbork 2006, s. 80.

7 Art. 49 i 50 Prawa o notariacie przewidują kolejno odpowiedzialność cywilną i dyscyplinarną. Odpowiedzialność cywilna jest osobistą odpowiedzialnością notariusza, ponieważ, mimo, że wykonuje pewne funkcje państwowe, nie jest on organem władzy publicznej. Co do odpowiedzialności karnej, zastosowanie mogą znaleźć przede wszystkim: art. 231 k.k. - przestępstwo nadużycia władzy lub niedopełnienia obowiązku, art. 266 k.k. - ujawnienie lub wykorzystanie informacji, art. 271 §1 k.k. - poświadczenia nieprawdy, art. 286 k.k. - oszustwa, gdzie notariusz byłby współsprawcą bądź pomocnikiem. Cz.P. Kłak, Notariusz i samorząd notarialny a obowiązek zawiadomienia o przestępstwie, „Nowy Przegląd Notarialny”, 2013, z. 1, s. 39-61; tenże, Notariusz a przestępstwo nadużycia władzy publicznej (art. $231 \mathrm{kk}$ ). Zagadnienia materialnoprawne i procesowe, „Rejent”, 2011/2; wyrok SN z 2.12.2002 r., sygn. akt IV KKN 273/01, wyrok SN z 17.10.2003 r., sygn. akt WA 48/03, OSNwSK 2003 nr 1, poz. 2168; Cz.P. Kłak, Notariusz a przestępstwo oszustwa - aspekty praktyczne, „Nowy Przegląd Notarialny”, 2012, nr 3; tenże, Ochrona tajemnicy notarialnej w polskim procesie karnym, „Prokuratura i Prawo”, 2013, z. 1.; Z. Sobolewski, Prawne konsekwencje zawiadomienia o przestępstwie w bezpieczeństwo i porządek publiczny. Historia, teoria, praktyka, Rzeszów 2003, s. 216.

$8 \quad$ Zob. R. Sztyk, Notariusz jako funkcjonariusz publiczny, „Rejent”, nr 11, 2006, s. 28-54; Zob. Cz.W. Salagierski, Pozycja notariusza w systemie organów ochrony prawnej, „Rejent” 2001, nr 5, s. 180-206. 
szczególny stopień pewności i mocy dowodowej. Notariusz jest organem ochrony prawnej, a jego działalność określana mianem jurysdykcji prewencyjnej, zmierza do wyeliminowania lub ograniczenia ryzyka przyszłego sporu ${ }^{9}$. Rozwiązania te, dotyczące ustroju i charakteru notariatu oraz obowiązków poszczególnych notariuszy, stanowią punkt wyjścia dla analizy ustawy o przeciwdziałaniu praniu pieniędzy oraz finansowaniu terroryzmu w zakresie w jakim dotyczy ona notariuszy.

\subsection{Obowiązki notariusza wynikające z ustawy o przeciwdziałaniu praniu pieniędzy oraz finansowaniu terroryzmu}

Wskazana w podtytule ustawa określa zasady oraz tryb przeciwdziałania praniu pieniędzy i finansowaniu terroryzmu, stosowania szczególnych środków ograniczających przeciwko osobom, grupom i podmiotom oraz obowiązki podmiotów uczestniczących w obrocie finansowym w zakresie gromadzenia i przekazywania informacji (art. 1) ${ }^{10}$. Za jeden $\mathrm{z}$ takich podmiotów, określonych w ustawie mianem instytucji obowiązanej, uznany został, w zakresie czynności notarialnych, dotyczących obrotu wartościami majątkowymi, notariusz (art. 2 ustęp pkt 1 , litera $\mathrm{n})^{11}$. W związku z tym nałożone zostały na niego następujące kategorie obowiązków:

1. obowiązki związane z gromadzeniem określonych informacji ${ }^{12}$;

$9 \quad$ Zob. T. Ereciński, Kilka uwag o pozycji ustrojowej notariusza, jego odpowiedzialności cywilnej oraz sądownictwie dyscyplinarnym, „Rejent” 2006, nr 5, s. 44-60.

10 Zob.: J. Grzywacz, Pranie pieniędzy, Warszawa 2010; W.C. Gilmore, Brudne pieniądze: metody przeciwdziałania praniu pieniędzy, Warszawa 1999; E. Pływaczewski, Przeciwdziałanie praniu brudnych pieniędzy z perspektywy międzynarodowej, PiP 2002, nr 8; J.W. Wójcik, Przeciwdziałanie praniu pieniędzy, Kraków 2004, s. 29; E. Pływaczewski, Pranie brudnych pieniędzy. Możliwości przeciwdziałania z uwzględnieniem roli systemu bankowego, Toruń 1993; B. Maruszewska-Baranek, Przeciwdziałanie i zwalczanie prania pieniędzy w Polsce po przystapieniu do Unii Europejskiej, „Zeszyty Prawnicze Wyższej Szkoły Ekonomii i Administracji w Bytomiu" 2008, nr 1/2.

11 Zob. W. Filipkowski, K. Prokop, Wolne zawody prawnicze a przeciwdziałanie praniu pieniędzy, PiP 2006, nr 2.

12 Dotyczy to w pierwszej kolejności transakcji, których równowartość przekracza 15 tys. euro. Obowiązek ten dotyczy zarówno transakcji przeprowadzanych w ramach jednej operacji, jak i kilku, jeżeli okoliczności wskazują, że są one ze sobą powiązane w jedną transakcję a ich podział dokonany był w celu uniknięcia obowiązku rejestracji (art. 8 ust. 1). Ponadto obowiązek ten rozciąga się na każdą transakcję, bez względu na jej wartość i charakter, której okoliczności wskazują, że wartości majątkowe pochodzą z nielegalnego lub nieujawnionego źródła. Są to tzw. transakcje „podejrzane”, rejestrowane bez względu na ich wartość i charakter (art. 8 ust. 3). Ustawa nie precyzuje, co znaczy pojęcie „transakcji podejrzanej”. Jej ocena dokonuje się w oparciu o rozmaite kryteria, pośród których podstawowym jest identyfikacja klienta i beneficjenta rzeczywistego oraz ustalenie jej celu, przy uwzględnieniu prowadzonej przez podmiot działalności; wyrok NSA z 4.3.2014 r., sygn. akt II GSK 1996/12. 
2. stosowanie wobec klientów środków bezpieczeństwa finansowego, na podstawie oceny ryzyka, (art. 8 b), która dokonywana jest w wyniku przeprowadzanych analiz, z uwzględnieniem w szczególności rodzaju klienta, stosunków gospodarczych, produktów lub celów transakcji (art. 10a) ${ }^{13}$;

3. prowadzenie rejestru i bieżącej analizy przeprowadzanych transakcji i dokumentowanie i odpowiednie zabezpieczenie i przechowywanie wyników analiz, rejestru transakcji wraz z dokumentami ich dotyczącymi (art. 8 a, art. 8 ust. 4 ustawy);

4. przekazywanie Generalnemu Inspektorowi Informacji Finansowej danych dotyczących zarejestrowanych transakcji z jednoczesnym nieujawnianiem tej okoliczności osobom nieuprawnionym, w tym stronom transakcji lub posiadaczom rachunku (art. 11) ${ }^{14}$;

5. niezwłoczne udostępnianie informacji dotyczących transakcji objętych przepisami ustawy na pisemne żądanie Generalnego Inspektora;

6. wstrzymanie transakcji (art. 16);

7. wprowadzenie $\mathrm{w}$ formie pisemnej wewnętrznej procedury, która uwzględni specyfikę instytucji obowiązanej oraz obszary podejmowanych działań (art. 10a) ${ }^{15}$;

8. obowiązek zapewnienia dla pracowników szkoleń, dotyczących identyfikacji czynności mogących mieć związek z przestępstwami prania pieniędzy oraz finansowania terroryzmu;

9. poddanie się kontroli stosowania przepisów ustawy, prowadzonej przez uprawnione podmioty, w tym udostepnienie pomieszczeń oraz przedłożenie dokumentów i materiałów niezbędnych do przeprowadzenia kontroli (art. 21-27).

13 Przy dokonywaniu analizy w celu określenia wysokości ryzyka, instytucja obowiązana powinna uwzględnić w szczególności następujące kryteria: (1) ekonomiczne - polegające na ocenie transakcji klienta pod względem celu prowadzonej przez niego działalności gospodarczej; (2) geograficzne - polegające na dokonywaniu transakcji nieuzasadnionych charakterem działalności gospodarczej zawieranych z podmiotami z państw, w których występuje wysokie zagrożenie prania pieniędzy i finansowania terroryzmu; (3) przedmiotowe - polegające na prowadzeniu przez klienta działalności gospodarczej wysokiego ryzyka z punktu widzenia podatności na pranie pieniędzy i finansowanie terroryzmu; (4) behawioralne - polegające na nietypowym, w danej sytuacji, zachowaniu klienta.

14 D. Szostek, Tryb dostarczania danych z rejestru Generalnemu Inspektorowi Informacji Finansowej przez notariuszy, „Rejent” 2004, nr 6, s. 192-203.

15 Wskazuje się, że procedura taka powinna zawierać zasady i kryteria: oznaczania transakcji jako podejrzanych, identyfikacji klientów, rejestracji transakcji oraz przekazywania informacji o transakcjach podejrzanych do Generalnego Inspektora. Ponadto powinna wskazywać zasady bezpiecznego przechowywania rejestru i dokumentów związanych z transakcjami oraz sposoby ich archiwizacji. Niezwykle istotne jest także precyzyjne ujęcie obowiązków spoczywających na osobie odpowiedzialnej za realizację przepisów ustawy (art. 10b); Nie opracowanie takich procedur czy opracowanie procedur niezapobiegających praniu pieniędzy jest objęte odpowiedzialnością karną. A. Golonka, Sankcje karne grożące za naruszenie obowiązków związanych z przeciwdziałaniem „praniu pieniędzy”, Cz. PKiNP 2006, nr 2, s. 155. 
Niewykonywanie bądź nienależyte wykonywanie tych obowiązków wiąże się z odpowiedzialnością podmiotów obowiązanych. Dyrektywa 2005/60/WE nałożyła na państwa członkowskie obowiązek wprowadzenia kar, które równocześnie będą karami efektywnymi, odstraszającymi, dyscyplinującymi, dolegliwymi ale i proporcjonalnymi (współmiernymi, adekwatnymi) ${ }^{16}$. Ustawa przewiduje dwa reżimy odpowiedzialności- administracyjny i karny. W założeniu rozwiązanie to miało służyć rozdzieleniu odpowiedzialności instytucji obowiązanych (odpowiedzialność finansowa) od odpowiedzialności osób działających w imieniu i na rzecz tych instytucji (odpowiedzialność karna). I tak, pierwszy z reżimów (art. 34) związany jest z nałożeniem przez Generalnego Inspektora kary pieniężnej (przy uwzględnieniu rodzaju i zakresu naruszenia, dotychczasowej działalności instytucji obowiązanej oraz jej możliwości finansowych (art. 34c ust. 2) za braki proceduralno- organizacyjne, w wysokości nie większej niż 750 tys. zł, a w razie naruszenia, o którym mowa w art. 34a pkt 5 - w wysokości nie większej niż 100 tys. zł (art. 34c ust. 1) ${ }^{17}$. Drugi reżim odpowiedzialności, odpowiedzialność karna, przewidziany jest $w$ art. 35, 36, 37a, 37b ${ }^{18}$. Za zrealizowanie znamion typów czynów zabronionych osobie działającej w imieniu lub interesie instytucji obowiązanej, wbrew przepisom ustawy grozi kara grzywny (art. 35 ust. 3, art. 37a) i kara pozbawienia wolności w wymiarze do lat 3 (art. 35 ust. 1,2) oraz od 3 miesięcy do 5 lat (art. 36) i od 6 miesięcy do lat 8 (art. 37) ${ }^{19}$.

16 A. Domasiewicz, Komentarz do art. 34 (a) ustawy o przeciwdziałaniu praniu pieniędzy oraz finansowaniu terroryzmu, Lex dla notariusza.

17 Wyrok WSA w Warszawie z 29.11.2011 r., syg. akt VII SA/Wa 1447/11, Lex nr 1155856; Wyrok WSA w Warszawie z 3.11. 2011 r., sygn. akt VI SA/Wa 1808/11, Lex nr 1155666.

18 Ustawa przewiduje karalność naruszenia przepisów ustawy w postaci m.in. niedopełnienia obowiązków: rejestracji transakcji, przekazania Generalnemu Inspektorowi dokumentów dotyczących tej transakcji lub przechowywania przez wymagany okres rejestru tych transakcji lub dokumentów dotyczących tej transakcji, zachowania środków bezpieczeństwa finansowego, zawiadomienia Generalnego Inspektora o transakcji, wprowadzenia wewnętrznej procedury, ujawnienia informacji osobom nieuprawnionym, odmowy przekazania Generalnemu Inspektorowi informacji lub dokumentów, przekazania nieprawdziwych danych lub zatajenie prawdziwych danych dotyczących transakcji, rachunków lub osób lub udaremnienie czy utrudnienie przeprowadzenie czynności kontrolnych. Przyjmuje się, że dla przypisania odpowiedzialności karnej obowiązek, do którego naruszenia dochodzi musi być wskazany szczegółowo a jego karnoprawne naruszenie zachodzi już wtedy, gdy niedopełniony zostanie tylko jeden ze szczegółowych obowiązków. A. Domasiewicz, Komentarz do art. 35 ustawy o przeciwdziałaniu praniu pieniędzy oraz finansowaniu terroryzmu, Lex dla notariusza.

19 R. Zawłocki, Obowiązekidentyfikacji prania brudnych pieniędzy na tle odpowiedzialności karnej, „Monitor Prawniczy” 2004, nr 9; A . Golonka, Ochrona obrotu gospodarczego przed przestępstwem prania pieniędzy $w$ świetle przeprowadzonych zmian - rozważania na gruncie zbiegu art. 35 ustawy o przeciwdziałaniu prania pieniędzy i art. 299 kk, WPP 2013, nr 1, s. 72-89; tejże, Podmiot przestępstwa „prania pieniędzy”, Cz. PKiNP 2006, nr 1, s. 121; tejże, Sankcje karne grożące za naruszenie obowiązków związanych z przeciwdziałaniem „praniu pieniędzy”, Cz. PKiNP 2006/2/155; B. Kolasiński Przeciwdziałanie praniu brudnych pieniędzy, „Prokurator” 2002, nr 1, s. 72-78; Dla prawidłowej kwalifikacji prawnej szczególnie doniosłe znaczenie ma relacja art. 35 ust. 1 ustawy z art. 231, 266 i 299 k.k. 


\section{Prawna i faktyczna problematyczność ustawy}

Odpowiedź na pytanie o jakość regulacji zawartej w ustawie o przeciwdziałaniu praniu pieniędzy oraz finansowaniu terroryzmu w zakresie dotyczącym notariusza, wymaga skonfrontowania jego statusu, przyjętego w systemie prawa z obowiązkami nałożonymi w komentowanej w ustawie. W pierwszej kolejności wskazać należy, że notariusz jest przede wszystkim strażnikiem i gwarantem bezpieczeństwa obrotu prawnego, a nie finansowego. Oznacza to, że jego rolą jest zabezpieczenie zgodności z prawem dokonywanych czynności, zgodnie z wymogami obowiązującego prawa i w jego świetle ocenianymi oświadczeniami stron. Obrót prawny jest rozumiany tutaj jako ogół stosunków cywilnoprawnych powstałych i powstających wskutek rozmaitych czynności prawnych podmiotów prywatnych oraz publicznych, wywołujących skutki wynikające z tych czynności, z zasad współżycia społecznego oraz z ustalonych zwyczajów (art. 56 kc). Obejmuje on wszelkie czynności urzędowe, umowy i oświadczenia, skierowane na wywołanie skutków w sferze prawa cywilnego, dokumenty wydawane w wykonaniu lub dla potwierdzenia wykonania obowiązków wynikających z zawartych umów ${ }^{20}$. Obejmuje on także zdarzenia faktyczne wpływające na zmianę sytuacji prawnej podmiotu. Dla ochrony bezpieczeństwa obrotu prawnego niezwykle istotne są ramy prawne, w których się on odbywa. Szczególnie doniosłe są tutaj przepisy prawa cywilnego (np. dotyczące formy czynności prawnych), tak materialnego jak i procesowego (dot. rodzaju dokumentów i ich mocy dowodowej) oraz te regulacje, które związane są z potwierdzeniem stanu własności czy posiadania (ustawa o księgach wieczystych i hipotece, prawo geodezyjne i kartograficzne).

Obrót finansowy natomiast powiązany jest bezpośrednio z przepływem środków płatniczych, do którego dochodzi wskutek wymiany dóbr i usług. Obrót prawny jest tylko podstawą dokonywania tych transferów w drodze gotówkowej bądź bezgotówkowej. Można więc powiedzieć, że obrót prawny i obrót finansowy pozostają ze sobą w określonym związku, natomiast ich cel i charakter są różne. W związku z tym, także rodzaj środków bezpieczeństwa oraz podmioty zobligowane do tej ochrony nie powinny być tożsame. Skuteczność ochrony, a w konsekwencji bezpieczeństwo, transparentność i przewidywalność obrotu prawnego i finansowego będą uzależnione od działań podjętych przez podmioty wyspecjalizowane. Podmiotem takim w zakresie obrotu finansowego bez wątpienia nie jest notariusz. Do jego obowiązków nie należy bowiem ustalanie rzeczywistego pochodzenia wartości będących przedmiotem transakcji ani pochodzenia środków,

Rzecz sprowadza się do udzielenia odpowiedzi na pytanie o charakter zbiegu, w jakim pozostają te przepisy - zob: O. Górniok $Z$ problematyki prawnokarnej prania pieniędzy na tle ustawy z dnia 16 listopada 2000 r., PS 2002, nr 4, s. 26.

20 Źródło: http://www.piit.org.pl/informacje/-/asset_publisher/K5uRJjKq87rd/content/ opinia-prawna-dot-wykladni-okreslenia-obrot-prawny-w-swietle-postanowien-ustawy-o-jezyku -polskim (dostęp 7.7.2015 r.). 
które służą zapłacie ceny. Notariusz zamieszcza jedynie w akcie notarialnym dane dotyczące ceny oraz terminu i sposobu jej zapłaty (gotówkowo, bezgotówkowo) oraz takich okoliczności jak: z jakiego majątku posiadane środki pochodzą, na jaki majątek rzecz jest nabywana oraz czy zaciągnięty został kredyt, co ma znaczenie z punktu widzenia wierzyciela i ustanowienia najdogodniejszego dla strony zabezpieczenia. Notariusz ustala to w oparciu o oświadczenia stron oraz przedłożone dokumenty. Nie jest jego ustrojowym zadaniem ustalanie przestępczego pochodzenia tych środków ani weryfikowanie dokonywanych czynności pod kątem ich potencjalnego związku z praniem brudnych pieniędzy czy finansowaniem terroryzmu. Co istotne także, notariusz nie ma ku temu żadnych realnych środków, ani prawnych ani faktycznych. Dane przedstawione przez klienta oraz informacje uzyskane z rejestrów publicznych, głównie ksiąg wieczystych i krajowego rejestru sądowego, są wystarczające do dokonania ważnej czynności prawnej w formie aktu notarialnego. Ważność ta jest ustalana na podstawie zgodności czynności prawnej z prawem oraz z zasadami współżycia społecznego. Informacje te nie są natomiast wystarczające aby zweryfikować daną czynność z punktu widzenia przewidzianych w ustawie, ogólnie zdefiniowanych, kryteriów: ekonomicznego, geograficznego, przedmiotowego czy behawioralnego ${ }^{21}$. Notariusz, w związku z pełnioną funkcją, ma mimo wszystko, dość selektywne informacje dotyczące swoich klientów. Nie prowadzi ich kompleksowej obsługi prawnej ani poradnictwa prawno-finansowego czy podatkowego. Nie musi posiadać wiedzy co do celów, zamierzeń kontraktowych czy inwestycyjnych podmiotów dokonujących czynności notarialnych. Nie zajmuje się ani strategią działań przedsiębiorcy ani zasadnością ekonomiczną i opłacalnością jego decyzji, co wydaje się konieczne do ustalenia związków decyzji danego podmiotu z praniem pieniędzy oraz finansowaniem terroryzmu. Jej brak uniemożliwia więc przeprowadzenie rzetelnej analizy, a następnie podjęcie zasadnych środków prawnych. W tym zakresie zatem ustawa nakłada na notariusza obowiązki, które są faktycznie niewykonalne, a mimo to sankcjonowane dolegliwą odpowiedzialnością administracyjną i karną. Zaznaczyć także należy, że dokonywane przez notariusza czynności mogą być potencjalnie, ze względu na swój charakter, w różnym stopniu związane z procederem prania pieniędzy. Wątpliwości budzi w szczególności darowizna, w ramach której nie dochodzi do przepływu środków pieniężnych. Niezależnie od tego, przy przekroczeniu ustawowej kwoty, będzie ona podlegała obowiązkowe rejestracji ${ }^{22}$.

Podsumowując, powiedzieć należy, że charakter i zakres kontroli nie odpowiada specyfice zawodu notariusza, który nie jest ani podmiotem świadczącym usługi finansowe ani podmiotem biorącym udział w gotówkowej czy bezgotówkowej

$21 \quad$ Cz.P. Kłak, Notariusz i samorząd notarialny..., s. 54.

22 Wyrok NSA z 4.3.2014 r., sygn. akt II GSK 1996/12. NSA stwierdził m.in., że organ nakładając karę pieniężną nie jest zobowiązany do wykazania, że transakcja w postaci umowy darowizny nieruchomości może być wykorzystana w procederze prania pieniędzy. 
transakcji. Nie ma również wystarczających środków, aby uzyskać dane (poza danymi koniecznymi dla dokonania czynności notarialnej), które dotyczyłyby osoby klienta, jego stosunków gospodarczych, produktów lub transakcji) i pozwalałyby realizować cel ustawy w postaci oceny ryzyka prania pieniędzy oraz finansowania terroryzmu. Notariusz ma wyłącznie realne środki, które służą zapewnieniu zgodności z prawem dokonywanych czynności czyli realizacji zadań, które należą do istoty notariatu. Za ich nienależytą realizacje, skutkującą szkodą strony, notariusz ponosi odpowiedzialność cywilną, karną lub dyscyplinarną. Natomiast obowiązki nałożone ustawą o przeciwdziałaniu praniu pieniędzy oraz finansowaniu terroryzmu, nawet przy założeniu wyższej niż przeciętna staranność, są niewykonalne. Wykraczają one daleko poza zadanie i rolę notariusza jako strażnika bezpieczeństwa obrotu prawnego, przewidzianą przede wszystkim przez Prawo o notariacie. Pomimo nieadekwatności obowiązków do roli notariuszy, część z nich, zwłaszcza dotyczących rejestracji transakcji przekraczających 15 tys. euro, wprowadzenia wewnętrznej procedury oraz szkoleń pracowników, jest rzeczywiście realizowana. Oznacza to, że poświęcany jest temu czas oraz, że ponoszone są określone koszty, obciążające notariuszy. Państwo w żaden sposób nie finansuje ani nie dofinansowuje realizowanych przez notariuszy, w gruncie rzeczy, państwowych zadań. Można więc powiedzieć, że dochodzi tutaj do naruszenia zasady równowagi oraz proporcjonalności w relacjach Państwo-notariusz, który poza tym, że pełni funkcje publiczne, jest równocześnie przedsiębiorcą, a więc podmiotem nastawionym na minimalizowanie kosztów działalności i osiąganie zysku.

Kolejną kwestią, która wymaga krytycznego komentarza jest kwestia odpowiedzialności administracyjnej, przewidzianej w ustawie, za nierealizowanie bądź nienależyte realizowanie obowiązków ustawowych. Zasadnicze wątpliwości dotyczą widełek, w jakich kara ta może być wymierzona. Ustawa stanowi, że górna granica (mogąca mieć zastosowanie także do notariuszy) to 750 tys. złotych. Norma nie wprowadza żadnego rozróżnienia podmiotowego, zrównując w konsekwencji osoby prawne z osobami fizycznymi, np. banki z podmiotami indywidualnymi, adwokatami czy notariuszami, niezależnie od rodzaju prowadzonej działalności. Indywidualizacja ma się dokonywać w toku postępowania, przy wydawaniu decyzji administracyjnej. Zgodnie bowiem z art. 34c, ustalając wysokość kary pieniężnej, Generalny Inspektor uwzględnia rodzaj i zakres naruszenia, dotychczasową działalność instytucji obowiązanej oraz jej możliwości finansowe. Oczywiście, są to okoliczności, które powinny być podstawą przypisania odpowiedzialności konkretnemu podmiotowi, ale wydaje się, że widełki zagrożenia karą są jednak zbyt szerokie, pozostawiając organowi szeroki zakres możliwej do wymierzenia kary. Zasadnym byłoby więc, jeżeli można pokusić się o wnioski de lege ferenda, ograniczenie możliwej sankcyjności poprzez stypizowanie naruszeń obowiązków ustawowych i odpowiadających im kar, w zależności od rodzaju tego naruszenia i podmiotu obowiązanego. Powinno się to dokonywać nie tylko w procesie stosowania prawa, ale już na etapie jego stanowienia, w procesie legislacyjnym. W ten 
sposób w większym stopniu byłaby realizowana zasada proporcjonalności i adekwatności wymierzanej kary pieniężnej.

Zarzuty dotyczące zbyt daleko idącej restrykcyjności ustawy czyni się także regulacji odpowiedzialności karnej. W komentarzach wskazuje się, że przewidziana odpowiedzialność karna za niedopełnienie obowiązków jest wyrazem radykalnego podejścia do sprawy. We wcześniejszych rozwiązaniach organ przeprowadzający kontrolę zawierał to we wnioskach pokontrolnych, zalecając uzupełnienie czy konsekwencje dyscyplinarne. Na gruncie obowiązującej regulacji musi złożyć zawiadomienie o podejrzeniu popełnienia przestępstwa ${ }^{23}$.

Następnym zagadnieniem, które budzi wątpliwości, to problem ewentualnego naruszenia tajemnicy notarialnej i w konsekwencji osłabienia zaufania dla zawodu oraz postrzeganie notariusza jako podmiotu współpracującego z organami ścigania. Ustawa jest elementem całego mechanizmu służącego ochronie bezpieczeństwa prawno- finansowego ${ }^{24}$. Jej sens opiera się na obowiązku współpracy notariusza z organami państwa w zakresie ścigania przestępstw prania pieniędzy oraz finansowania terroryzmu. Polega on przede wszystkim na zawiadamianiu o podejrzeniu popełniania przestępstwa oraz informowaniu Generalnego Inspektora o istotnych z punktu widzenia celów ustawy, okolicznościach. Z kolei sens tajemnicy notarialnej, tak jak każdej zawodowej, polega na nieujawnianiu okoliczności, o których jej depozytariusz dowiedział się przy wykonywaniu swoich obowiązków. Obowiązek zachowania tajemnicy notarialnej ma charakter publicznoprawny, jest konsekwencją wykonywania zawodu zaufania publicznego ${ }^{25}$ jest jednym $z$ podstawowych obowiązków notariusza, na co wskazuje sama rota ślubowania oraz treść ustawy prawo o notariacie ${ }^{26}$. Z norm tych wynika, że obowiązek dochowania tajemnicy zawodowej jest przyjętą i nie budzącą wątpliwości zasadą, której naruszenie jest możliwe w przewidzianych w ustawach, wyjątkowych okolicznościach. Analizując zagadnienie w kontekście ustawy o przeciwdziałaniu praniu pieniędzy oraz finansowaniu terroryzmu trzeba wspomnieć o „ogólnych” przepisach, zawierających obowiązek zawiadomienia o popełnieniu przestępstwa. Chodzi tu przede wszystkim o art. $304 \S 1 \mathrm{kpk}$, przewidujący społeczny obowiązek zawiadomienia o popełnieniu przestępstwa oraz $\S 2 \mathrm{kpk}$, przewidujący prawny obowiązek, przy czym, jak wynika z treści przepisu, nie obciąża on poszczególnych notariuszy, a organ kolegialny samorządu notarialnego, uprawniony do działania w imieniu instytucji samorządowej ${ }^{27}$. Ponadto art. $240 \mathrm{kk}$ zawiera typ czynu zabronionego polegającego na zaniechaniu denuncjacji o popełnieniu enumeratywnie

23 A. Domasiewicz, Komentarz do art. 35 ustawy o przeciwdziałaniu praniu pieniędzy oraz finansowaniu terroryzmu, Lex dla notariusza.

$24 \quad$ Cz.P. Kłak, Notariusz i samorząd notarialny..., s. 39-71.

25 Cz. P. Kłak, Ochrona tajemnicy notarialnej..., s. 29.

26 Art. 15 §1.; art. 18 Prawa o notariacie.

27 Podmiotami zobowiązanymi do udzielenia informacji jest Krajowa Rada Notarialna oraz rada izby notarialnej. 
wyliczonych w przepisie przestępstw. Obowiązek ten nie jest zindywidualizowany, dotyczy wszystkich, zatem także i notariusza ${ }^{28}$. Z przepisów tych wynika, że oprócz art. $240 \mathrm{kk}$, brak normy prawnej zawierającej prawny obowiązek denuncjacji. Jest to wynik kilku założeń systemowych. Po pierwsze, ustrojowa rola notariusza nie polega na byciu denuncjantem, po drugie, obowiązek współpracy z organami ścigania wiąże się zwykle z ograniczaniem praw i wolności obywateli, co w państwie prawa należy minimalizować i po trzecie, obrót prawny jest wystarczająco chroniony przy pomocy innych mechanizmów ${ }^{29}$. W konsekwencji na notariuszu nie ciąży generalny prawny obowiązek zawiadomienia o popełnieniu przestępstwa. Ma natomiast do tego prawo realizując obowiązek społeczny, co nie będzie stanowiło naruszenia tajemnicy zawodowej. Zawiadomienie o przestępstwie, jak się przyjmuje w literaturze, mieści się bowiem w granicach prawa, tak więc art. 18 prawa o notariacie nie eliminuje prawa do zawiadomienia o przestępstwie ${ }^{30}$.

Ustawa o przeciwdziałaniu praniu pieniędzy oraz finansowaniu terroryzmu zmienia po części przyjęty model rozwiązań, ponieważ nałożone w niej na notariusza obowiązki noszą znamiona denuncjacji ${ }^{31}$. Wprawdzie udzielanie informacji Generalnemu Inspektorowi jest dokonywane na podstawie i w granicach prawa, budzi jednak wątpliwości ${ }^{32}$. Ustawodawca przyjął założenie, że realizacja celów ustawy w postaci przeciwdziałania pewnym formom przestępczości jest istotniejsza niż dochowanie i ochrona tajemnicy zawodowej. Rozwiązanie to jest krytykowane jako zbyt daleko idące, naruszające jedną z podstawowych zasad wykonywania zawodu notariusza, a ponadto niepotrzebne. Podważa się zarówno sam obowiązek przekazywania danych oraz jego zakres. Podnosi się, że zasada ochrony tajemnicy zawodowej jest bardziej doniosła niż wątpliwe efekty zwalczania przestępczości, którym ujawnienie określonych informacji ma służyć. Zarzuca się także, że przekazywane informacje nie są w należyty sposób chronione, co dodatkowo naraża osoby, których dane są ujawniane, na niebezpieczeństwo niezgodnego z prawem ich wykorzystania.

Z kolei jako argument na rzecz zasadności i celowości ustawowych rozwiązań można przywołać rację, że skoro prawny obowiązek mają instytucje państwowe i samorządowe, to również notariusz jako funkcjonariusz publiczny, wykonujący pewne czynności urzędowe, taki obowiązek powinien mieć. Uwiarygadniałoby to dodatkowo notariusza, który byłby postrzegany przez społeczeństwo pozytywnie, jako element bezpieczeństwa obrotu prawnego na zbiegu prawa cywilnego z prawem karnym. Przeciwnicy tego rozwiązania widzą to oczywiście dokładnie odwrotnie. Zarzucają ustawie, że poprzez nałożone obowiązki notariusz może

\footnotetext{
Cz. P. Kłak, Notariusz i samorząd notarialny..., s. 46.

Ibidem, s. 51.

Ibidem, s. 49.

Ibidem, s. 52.

32 Z. Sobolewski, Prawne konsekwencje zawiadomienia o przestępstwie $w$ bezpieczeństwo i porządek publiczny. Historia, teoria, praktyka, Rzeszów 2003, s. 216.
} 
być postrzegany jako osoba współpracująca z organami ścigania, co ma zdecydowanie wydźwięk pejoratywny i w konsekwencji nie sprzyja budowaniu zaufania, koniecznego dla dobrego i sprawnego funkcjonowania notariatu. Innymi słowy, notariusz z powiernika staje się donosicielem. Z takim stanowiskiem łączy się często dodatkowy argument, mianowicie, że rozwiązania prawne, tak daleko ingerujące w sferę wolności podmiotów gospodarczych, naruszają również zasadę domniemania niewinności. Przyjmuje się tu bowiem założenie, że każdy może być potencjalnym uczestnikiem procederu prania pieniędzy czy finansowania terroryzmu i w związku z tym jego działania na każdym etapie ich podejmowania są kontrolowane przez rozmaite organy władzy państwowej. U podstaw systemu prawnego leży natomiast domniemanie niewinności ${ }^{33}$, które może być obalone jedynie prawomocnym wyrokiem skazującym. Wyrok taki ma być wydany po przeprowadzeniu postępowania, w którym ciężar udowodnienia winy spoczywa na oskarżycielu. Oznacza to, że nikt nie może być zmuszony do wykazywania swojej niewinności. Zdaniem krytyków ustawy, przerzuca ona właśnie ciężar dowodu z oskarżyciela zobowiązanego do wykazania winy na uczestnika obrotu, zmuszonego de facto do wykazywania swojej niewinności w zakresie związków z praniem pieniędzy czy finansowaniem terroryzmu. Stanowi to, rzecz jasna, naruszenie podstawowych zasad porządku prawnego i przesądza o niekonstytucyjności powołanych przepisów ${ }^{34}$.

Rozwiązaniom ustawowym należy zarzucić także nieprecyzyjność terminologii prawniczej. Tytułem przykładu można tu wskazać definicję legalną „beneficjenta rzeczywistego” oraz zawarte w niej sformułowania takie jak „właściciel osoby prawnej”, czy „sprawowanie kontroli nad klientem i posiadanie wpływu na osobę fizyczną" ${ }^{35}$. Przy pierwszym z nich powstają problemy z ustaleniem jego znaczenia na gruncie terminologii i instytucji prawa cywilnego oraz handlowego. Wynikają one z tego, że takie pojęcie nie występuje. Właścicielem osoby prawnej nie jest bowiem ani udziałowiec czy akcjonariusz ani członek zarządu czy jej fundator. Zastanawiające jest także, co ustawodawca rozumiał pod pojęciami „sprawowania kontroli nad klientem” i „posiadania wpływu na osobę fizyczną”. Czy chodzi tutaj o kontrolę i wpływ mający charakter prawno- instytucjonalny, faktyczny czy może oba? Wydaje się, że każda z tych interpretacji jest w równym stopniu uprawniona. Pytaniem otwartym pozostaje, które ze znaczeń wybierze notariusz zobligowany do stosowania (a wiec i wykładni) ustawy oraz czy Generalny Inspektor i prokurator podzielą jego intuicję interpretacyjną. W każdym razie, w procesie stosowania prawa może dochodzić do wielu niejasności i wątpliwości interpretacyjnych, skutkujących rozbieżnościami w orzecznictwie. Jest to tym bardziej niepokojące,

$33 \quad$ Art. 42 ust. 3 Konstytucji RP; dodatkowo przewiduje ją także art. 5 k.p.k.

34 Źródło: http://czasopisma.beck.pl/nc/aktualnosc/tajemnica-zawodowa-prawnikow-anowelizacja-ustawy-o-praniu-brudnych-pieniedzy (dostęp 7.7.2015 r.).

35 Art. 2 pkt. 1a ustawy o praniu pieniędzy oraz finansowaniu terroryzmu. 
że przyjęcie określonej interpretacji może decydować o pociągnięciu podmiotu obowiązanego do odpowiedzialności administracyjnej lub karnej. Naczelną zaś zasadą tych dziedzin prawa, które mają charakter restrykcyjny, a bez wątpienia należy do nich prawo administracyjne i karne, jest to, aby były jednoznaczne, a pojęcia precyzyjnie określone. Wiąże się to z daleko idącą ingerencją w sferę praw i wolności podmiotów - osób fizycznych i osób prawnych.

Wskazując na problematyczność przyjętych rozwiązań warto na koniec zwrócić także uwagę na niestaranność w formułowaniu treści ustawy. W art. 2 pkt 10 ustawa stanowi, że praniem brudnych pieniędzy jest także „współdziałanie, usiłowanie popełnienia, pomocnictwo lub podżeganie w przypadkach zachowań określonych w lit. a-c , a więc zamianie lub przekazaniu wartości majątkowych pochodzących z działalności o charakterze przestępczym lub z udziału w takiej działalności, w celu ukrycia lub zatajenia bezprawnego pochodzenia tych wartości, ukryciu lub zatajeniu prawdziwego charakteru wartości majątkowych lub praw związanych z nimi, nabyciu, objęciu w posiadanie albo używaniu wartości majątkowych pochodzących z działalności o charakterze przestępczym lub udziału w takiej działalności. Ustawodawca przemieszał tutaj formy zjawiskowe oraz formę stadialną popełnienia przestępstwa, zamiast konsekwentnie i dla porządku wymienić je w ramach danej kategorii ${ }^{36}$.

\section{Zakończenie}

Przytoczone powyżej uwagi wskazują na kontrowersyjny charakter rozwiązań przyjętych w ustawie o przeciwdziałaniu praniu pieniędzy oraz finansowaniu terroryzmu. Dotyczy to zarówno samych założeń tej ustawy jak i ich realizacji w postaci treści poszczególnych przepisów oraz ich efektywności. Można więc powiedzieć, że sformułowane uwagi dotyczą tak sfery normatywnej jak i faktycznej, związanej z urzeczywistnieniem celów aktu prawnego. Ich rodzaj, waga oraz zakres poddają w wątpliwość przepisy ustawy o przeciwdziałaniu praniu pieniędzy oraz finansowaniu terroryzmu w zakresie $\mathrm{w}$ jakim czynią notariuszy podmiotami obowiązanymi.

Podsumowując, co do założeń ustawy, z perspektywy systemu prawnego i jego pryncypiów, ustawie zasadnie zarzucić należy nieadekwatność i nieproporcjonalność nałożonych na notariuszy obowiązków w stosunku do wynikających z ustroju notariatu obowiązków notariuszy. Zasadniczy problem dotyczy więc obarczenia obowiązkami Państwa notariuszy, do zadań których nie należy udział w wykrywaniu i zwalczaniu przestępstw. Notariusz, w ramach dokonywanych

36 Art. 18 k.k. jako formy zjawiskowe wymienia współsprawstwo, podżeganie, pomocnictwo, sprawstwo kierownicze, sprawstwo polecające. Forma stadialną wymienianą w ustawie jest natomiast usiłowanie, uregulowane w art. $13 \mathrm{k} . \mathrm{k}$. 
czynności, nie jest w stanie stwierdzić, czy czynność ta jest podejrzana a więc niezasadna, nietypowa, niejasna czy nadzwyczajna, z punktu widzenia prowadzonej przez przedsiębiorcę działalności, w tym celowości czy opłacalności podejmowanych decyzji ${ }^{37}$. Rodzaj prowadzonej przez notariuszy działalności nie daje możliwości realizacji celów ustawy. Notariusz ma wprawdzie zwykle bezpośredni kontakt z klientem, ale nie uzyskuje wiedzy koniecznej do stwierdzenia wystąpienia przesłanek przestępności czynu. Stworzenie warunków ochrony praw i interesów podmiotów prawnych uczestniczących w ściśle rozumianym obrocie prawnym spoczywa po części na notariuszach (głównie przy sprawdzaniu przedłożonych dokumentów), natomiast stworzenie warunków ochrony praw i interesów podmiotów prawnych w ramach obrotu finansowego, w tym, w zakresie objętym ustawą, powinno obciążać organy władzy państwowej, które instytucjonalnie, organizacyjnie i kompetencyjnie są do tego powołane i przysposobione. Notariusz pełni wprawdzie funkcje państwa ale „jedynie” poprzez dokonywanie czynności notarialnych o charakterze urzędowym, których efektem są dokumenty urzędowe $^{38}$. Nie jest natomiast organem dochodzeniowo-śledczym ani kontrolnym czy nadzorczym.

Co do treści poszczególnych przepisów, ustawie można zarzucić brak wymaganej staranności wynikającej z zasad techniki legislacyjnej. Niepoprawnym jest bowiem takie formułowanie przepisów, które już na wstępie powoduje niejasności interpretacyjne, a w konsekwencji rozbieżności w orzecznictwie. Narusza to zasadę pewności prawa i przewidywalności rozstrzygnięć. Ponadto poddaje w wątpliwość także założenie o racjonalności prawodawcy.

I wreszcie co do jej efektywności, stwierdzić należy, że jest ona znikoma co najmniej z dwóch powodów ${ }^{39}$. Pierwszy wynika ze wspomnianej już wyżej, niewielkiej wiedzy uzyskiwanej przez notariusza podczas czynności, która nie daje możliwości oceny transakcji z punktu widzenia przeciwdziałania prania pieniędzy (w szczególności ustalenia źródeł pochodzenia pieniędzy) oraz finansowania terroryzmu (ich przeznaczenia). Podkreślić przy tym należy, że nawet ponadprzeciętna staranność notariusza nie będzie rekompensować braku wiedzy, której nie da się zdobyć przy dokonywaniu czynności notarialnych. Nie bez znaczenia jest również, że oprócz pełnienia funkcji publicznych, notariusz jest także przedsiębiorcą, dla którego, oprócz działania zgodnego z prawem, niezwykle istotna jest także sprawność oraz szybkość. Jest to okoliczność związana z wymogami rynku oraz oczekiwaniami klientów, która wpływa na decyzje notariuszy, działających

37 Źródło: http://czasopisma.beck.pl/nc/aktualnosc/tajemnica-zawodowa-prawnikow-anowelizacja-ustawy-o-praniu-brudnych-pieniedzy (dostęp 7.7.2015 r.).

38 A. Oleszko, Status prawny notariusza w systemie ustroju państwowego, „Rejent” 2005, nr 12, s. 12.

39 Źródło: www.mf.gov.pl/_files_/giif/publikacje/spr_2011_v8a.pdf (dostęp: 21.8.2012 r.). Sprawozdanie Generalnego Inspektora Informacji Finansowej z realizacji ustawy z dnia 16 listopada $2000 \mathrm{r}$. o przeciwdziałaniu praniu pieniędzy oraz finansowaniu terroryzmu w 2011 roku. 
w realiach wolnego rynku i konkurencji. Nałożenie tak daleko idących obowiązków, uważanych powszechnie za niewykonalne, może w konsekwencji skłaniać do ich nierealizowania, niejako „z zasady”. Gdyby natomiast były one realne, można by oczekiwać, że staranny rejent będzie postępował zgodnie z ustawą, bez uszczerbku dla „zarobkowej” strony zawodu. Oznacza to, że nieadekwatność obowiązków do zadań notariuszy nie tylko stanowi naruszenie ustroju notariatu ale także powoduje nieskuteczność i brak efektywności przepisów. Są one także niepotrzebne i z tego powodu, że notariusz przekazuje także wypisy aktów notarialnych, zawierających znaczną cześć informacji przekazywanych do Generalnego Inspektora, do urzędów skarbowych. Drugi powód nieefektywności wynika z zakresu obowiązku rejestracji transakcji, którym (z uwagi na przedmiot czynności notarialnych- głównie obrót nieruchomościami) objęta jest większość dokonywanych czynności. Ilość zatem przekazywanych Generalnemu Inspektorowi danych ze wszystkich kancelarii notarialnych w kraju, uniemożliwia realną ocenę tych czynności z perspektywy zagrożenia popełnienia przestępstwa prania brudnych pieniędzy czy finansowania terroryzmu.

Jako komentarz kończący powyższe rozważania warto przytoczyć stwierdzenie, które, mimo, że dotyczy adwokatów (także objętych tą regulacją), ma znaczenie również dla notariuszy. „Zastanówmy się, kto jest objęty skutkami „bezprawia” omawianej ustawy. Myślę, że są to trzy podmioty: po pierwsze każdy indywidualnie wykonujący praktykę adwokat, po drugie samorząd adwokacki, po trzecie nasz klient ${ }^{40}$. Sądzę, że jest ono tak samo aktualne kolejno: wobec notariusza, samorządu notarialnego jak i klienta.

\section{Security of legal and financial transactions. The duties of the notary public in the light of the law on the prevention of money laundering and terrorist financing}

The law on the prevention of money laundering and terrorist financing determines the principles and the procedure aimed at preventing money laundering and terrorist financing, the use of special restrictive means against persons and groups and eventually, the duties of subjects who participate in financial transactions, notaries public included. The responsibilities of the notary public, arising from the model of notarial institution and boiling down to guarantee the security of legal transactions have been supplemented with the following duties: registration of transactions, sending information to the GIIF (General Inspector of Financial Information) and notary public'being subject to inspections.

Since the very beginning this regulation by law has been raising doubts which regard not only the rules themselves, their legitimacy and effectiveness,

40 Źródło: http://czasopisma.beck.pl/nc/aktualnosc/tajemnica-zawodowa-prawnikow-anowelizacja-ustawy-o-praniu-brudnych-pieniedzy (dostęp 7.7.2015 r.). 
but also the wording of the text. The reason for the controversies concerning this law is that within his/her responsibilities, the notary public is not obliged either to ascertain whether the money is of criminal origin or to verify his/her transactions in view of money laundering of financing of terrorism. The notary public has neither legal nor practical measures to adopt in this field; moreover, the State offers neither money nor any financial coparticipation in performing such tasks. In addition, in the course of legal transactions, the notary's professional secrecy might be infringed, which means breach of professional confidentiality as well. In view of such objections, of particular doubt is the possible pecuniary penalty provided either for failing or incorrect application of the law, all the more so because those items are inaccurate and in defiance of the principles of law making techniques. 